\title{
Growth performance in Portugal since the 1960's: a simultaneous equation approach with cumulative causation characteristics.
}

\begin{abstract}
The aim of this paper is to explain growth performance in Portugal in the last decades through a multi-equation system with cumulative growth characteristics. The model uses a demandorientated approach to determine the main relationships which explain growth through a virtuous cycle. The idea is to identify the driving forces of growth with causal linkages and feedback tendencies that turn the process self-sustained. The multi-equation growth model is estimated by $3 S L S$ to capture more efficiently the interrelations between the main growth forces and to control for the endogeneity of the regressors. Our evidence shows that the proposed model can successfully be used to explain the Portuguese growth performance, highlighting the importance of exports competitiveness as the key factor in this process. The cumulative growth process can be interrupted at some points mainly due to the incapacity of transferring productivity gains into domestic prices and to turn the economy more competitive. Capital accumulation is also shown not to affect productivity growth and domestic prices not to improve exports competitiveness. These are the main drawbacks of the Portuguese economy that could explain the failure to achieve higher growth rates in the last decades.
\end{abstract}

JEL code: $\mathrm{O} 1, \mathrm{O} 3, \mathrm{O} 4$

Keywords: cumulative growth, multi-equation system, exports competitiveness, productivity gap, $3 S L S$ regressions 


\section{Introduction}

The Keynesian demand-orientated approach admits, contrary to the neoclassical supplyled growth theory, that demand, especially exogenous demand (through exports) is the main driving force of growth. When external imbalances occur (mainly due to current account deficits), it is income that adjusts to preserve the balance-of-payments equilibrium. In this approach, growth is not constrained by the supply of factor inputs and productive factors are endogenous to the growth process, transferred to locations where demand is stronger and not to where relative prices are more favourable, as the neoclassical theory assumes.

The demand-orientated approach to growth takes into account the existence of heterogeneity across economies and specific structures, where free trade and free factor mobility can lead to uneven economic development. Consequently, the tendency for convergence of the neoclassical analysis, due to the lower stock of capital in poorer economies and diminishing returns to scale of the productive factors, does not occur automatically.

The existence of increasing returns to scale especially in the non-primary sector will induce a cumulative causation growth process with circular tendencies towards sustainable growth. Once an economy gains a competitive growth advantage (through exports) it will preserve it and may even extend it further making difficult for others to compete on the same activities.

The core of the cumulative causation growth process is the "Verdoorn's Law", assuming that productivity growth is endogenous, depending on the growth of output (mainly of industrial output). This relation captures the increasing returns properties 
(both static and dynamic) found in the industrial sector and turns the growth process virtuous with cumulative causation characteristics.

The cumulative causation model composed by a multi-equation system will be tested for the Portuguese economy to verify whether this approach is relevant to explain the growth performance of this country in the last decades. A complete growth model with structural interrelated equations will be estimated simultaneously by $3 S L S$, expressing the main features of the cumulative growth process with circular characteristics. Special attention will be given to the productivity gap between Portugal and the leader (the $U S A$ ), aiming to capture the possibility for catching-up tendencies in technology and innovation activities.

The Portuguese economy is characterized by producing mainly non-tradable goods and the share of non-tradable has increased after Portugal joined the EU in 1986. Structural funds were invested mostly on infrastructure networks benefiting the service sector in detriment of the industrial sector. On the other hand exports are of low-medium technology and mostly of low value-added. ${ }^{1}$ Adding to this deficient productive structure, the accumulation of public and external debts due to low competitiveness they can be considered as the main reasons preventing the economy from growing at sustainable rates. The main interest of our paper lays in checking whether the model we propose is able to detect the main drawbacks that prevented the economy from growing faster especially in the post-accession to the EU period. These drawbacks can also be the causes of the recent debt crisis in Portugal that forced the country to ask for external intervention. 
The outline of the study is the following: in section 2, some theoretical considerations related to the cumulative causation principle are reviewed. In section 3 historical trends of the main variables used in the model are explained. In section 4 the structural multiequation model is presented and the virtuous circle of cumulative growth is described. Section 5 reports the estimation results and discusses the relevance of the cumulative causation model to explain the Portuguese economic performance. The final section concludes.

\section{The cumulative causation principle}

The process of cumulative causation growth was used by Myrdal (1957) to explain international differences in the level of development between countries. Labour migrates from poor to rich countries seeking for better remuneration and better employment opportunities, enhancing demand and growth in the destination country. Capital migrates to developed countries where risk is lower, tax incentives are generous, skilled labour is available and profit perspectives are higher. Trade is unfavourable to the developing countries, producing mainly primary commodities with inelastic demand and low value-added. Trade is more advantageous to the developed countries, specialising in increasing returns to scale activities with high income-elasticity of demand, and high value-added. Efficiency-wages - as Kaldor (1978) defined "the index of money wages divided by the index of productivity"- have the tendency to fall more rapidly in faster-growing countries as a result of gains in productivity. Therefore, developed countries gain a cumulative competitive advantage, especially in manufacturing commodities. Spread effects - with favourable repercussions on backward countries - are weaker at the international level than within nations, resulting in persistent and sometimes even widened international differences on growth. 
Kaldor (1957; 1966) developed his growth theory using many of Myrdal's ideas and criticised the neoclassical approach of exogenous growth as unrealistic and unable to explain differences in growth rates between countries or regions. In contrast to the neoclassical doctrine of constant returns to scale of the reproducible factors, Kaldor attributed to industry and manufacturing the exclusive role of generating increasing returns to scale through the workings of the "Verdoorn's Law". Once an economy obtains a growth advantage (mainly in exports) it will tend to sustain it at the expense of other economies, because faster output growth leads to faster productivity growth through the Verdoorn's effect. Higher productivity in turn reduces efficiency-wages and consequently prices, turning the economy more competitive expanding the growth process in a circular and cumulative way. ${ }^{2}$ At the heart of the cumulative growth process stands the hypothesis of increasing returns to scale associated with the "Verdoorn's Law", reflecting some kind of technological progress and turning the growth process self-sustained. The increasing returns are not only static, related to the scale of production, but also dynamic, coming from learning-by-doing, induced investment, embodied technical progress, external economies, among other factors. For Kaldor $(1970 ; 1981)$ the competitive industry is responsible for the polarisation phenomenon and the poles of economic activities are on the industrial sector. On the other hand, exports that are mainly produced in the industrial or manufacturing sectors are the most potent element of exogenous demand, with higher multiplier effects on national income.

The cumulative process develops in a virtuous cycle favouring the economy with the initial competitive advantage and making it difficult for other economies to establish the same activities. This is the essence of the theory of cumulative causation growth, that explains the phenomenon of divergence between the centre and the periphery or between industrial and agricultural economies, and hence between developed and 
developing economies. Developing or less developed economies have not the ability to explore activities with increasing returns to scale properties and to generate a cumulative process of expanding growth. Trade openness will benefit economies that have the ability to explore activities with substantial economies of scale and produce competitive commodities. The message which can be drawn from Kaldor's model of cumulative causation is that faster growth can be obtained by making the economy more competitive and/or altering the industrial structure in a way to produce goods with higher income-elasticity of demand and obtaining higher gains of productivity reflected in the Verdoorn's relation.

Some studies attempted to test empirically the validity of the cumulative growth model, among them, Amable (1993), Atesoglu (1994), Pini (1996), Targetti and Foti (1997), De Benedictis (1998), and more recently Fingleton (2000), Greunz (2001), Castellacci (2002) and Léon-Ledesma (2002). ${ }^{3}$ Most of them are cross-country or cross-region studies, using diverse sets of equations to describe the cumulative growth process and different proxies to express the technology gap. A summary of these studies including a technology gap is given in Table 1, which is self-explained.

\section{[Insert Table 1 here]}

Our study differs from the previous ones in two main aspects: it uses time series data ${ }^{4}$ to explain growth performance of a unique country, Portugal; the structural model and some variables are different from those of the previous studies as we will explain in the next sections.

\section{Historical trends of the main variables}


In line with the previous considerations, we adopt a demand-driven approach of circular and cumulative causation, in order to verify whether such a perspective is adequate to explain the Portuguese growth performance throughout the last decades. The first step is to define the variables that enter the model and analyse their evolution over time. ${ }^{5}$ Table 2 displays some descriptive statistics of the variables to be used in the structural model, namely the mean, the standard deviation, the minimum and the maximum values. Combining this information with that from the figures of the evolution of variables over time, we are able to observe important tendencies throughout the last decades.

The first two rows of Table 2 and Figure 1 show that for most of the years Portuguese growth $(y)$ exceeded that of the OECD countries $(z) .{ }^{6}$ The exception has been during the period 1983-1985 where Portuguese growth was lower than the OECD average explained by the restrictions imposed by the IMF to solve the external debt crisis. More recently, from 2002 onwards, the country has been experiencing a slowdown in growth, more evident than in the OECD countries, and this period coincides with the participation of Portugal in the EMU. The decline of growth in the latter period can be attributed to the loss of competitiveness in external markets. Unlike Portugal, the OECD growth average does not display negative values in any occasion. Both growth rates declined throughout the period but for Portugal the decrease has been more pronounced: Portugal's growth dropped from $7.6 \%$ in 1965 to $1.4 \%$ in 2006 , while in the OECD countries the fall was from $5.1 \%$ in 1965 to $3.1 \%$ in 2006 .

\section{[Insert Table 2 and Figure 1 here]}

From the third row of Table 1 and the Figure 2, it can be seen that exports grew on average around $6 \%$ per annum for the whole period fluctuating within a wide range, 
although it becomes narrower after 1986, the year that Portugal joined the EU. Export growth attained a peak of $33 \%$ in 1979 and the lowest record in 1975 , of about $-16.4 \%$, following the year of the change of the political regime. Considering the whole period, the annual growth rate fell from $13.5 \%$ in the beginning of the period to $8.7 \%$ in 2006 . The growth of exports is substantially lower after Portugal joined the EU revealing difficulties in competing in free external markets.

It is interesting to analyse the structure of exports during the global period which shows a significant change. From 1967 to 1973 (includes the accession to EFTA and the transition to democracy), products from the primary sector without substantial transformations lead the export sector, namely paper pulp and canned food (fish, tomato). Also, intermediate textile products, clothes and naval repair are part of the Portuguese main exports in the same period. Between 1974 and 1985 (the pre-accession to the EU period), textiles, footwear, automobile components and paper pulp were on the top of exports. During the first years of the European membership (1986-1999), the main exports were associated with foreign investments, like those of AutoEuropa (car industry) and Siemens (electronics). Footwear, ceramics, cars and electronic devices were in the top of the list of exported goods. From 2000 onward, with the adoption of the common currency and the increased competition from the new developing countries, Portugal lost competitiveness in the textile, footwear and the construction material sectors with a severe decline in exports. The metallic, automobile and paper industries were reinforced, while the chemical industry started to gain relevance in the export sector (source: Caixa Geral de Depósitos, 2012). In general there is a shift from the traditional primary sector of low technology to the low-medium technology exporting sectors. 


\section{[Insert Figure 2 here]}

As Table 1 shows, domestic prices $(p)$ grew on average faster than import prices $(\mathrm{pm})$ (10.37\% against $9.13 \%)$. Figure 3 shows that the growth of domestic prices was always non-negative and reached its maximum in 1977, prior to the second oil crisis that aggravated prices worldwide. After Portugal joined the EU, the growth of domestic prices is generally faster than that of import prices and this is probably due to the removal of import duties. During the whole period and especially in the post-accession period Portugal behaves poorly as far as price competitiveness in international markets is concerned. As we will explain bellow, this is because money wages grew faster than labour productivity turning the economy less competitive.

\section{[Insert Figure 3 here]}

Comparing the growth of the nominal compensation per employee $(w)^{7}$ with the growth of labour productivity ( $p r o d)$ in Figure 4, we are able to infer about the growth of efficiency wages. The first aspect to notice is that only in 1968 the growth of productivity was faster than that of nominal wages. In the remaining years, the growth of nominal wages exceeded that of productivity and this is pointed out as a persistent problem for Portugal, affecting its competitiveness both domestically and abroad. Over the whole period nominal wages grew on average $14.13 \%$ per annum, much higher than the average growth of productivity of 3.39\% (see Table 1). A striking aspect is that the growth of productivity is declining over time, from $7.4 \%$ in the beginning of the period to $0.9 \%$ in 2006 . Although nominal wages growth has declined over time (because of lower inflation rates) the gap between the latter and productivity growth remains substantial over time, influencing negatively the economy's competitiveness. When we consider the growth of real compensation per employee $(r w)$ in the analysis, the picture 
is slightly different. Although the average growth of real wages $(3.46 \%)$ is slightly faster than the average growth of productivity (3.39\%), the difference between the two has consistently been diminishing over time.

\section{[Insert Figure 4 here]}

The technology gap (gap) is defined as one minus the ratio of the Portuguese productivity level relatively to the USA's, considering that the latter is the leading country in productivity gains due to higher innovation and technology advances. When the gap is declining towards zero it means that Portugal is catching-up with the leader over time, making progresses in productivity. From Table 1 it can be observed that the Portuguese productivity level, on average, corresponds to only $56 \%$ of the USA's but Figure 5 shows that some improvement has taken place over time. In fact, the gap in productivity is declining throughout the period (from 70.92 in 1965 to $55.42 \%$ in 2006), giving some evidence of convergence relatively to the leader. However, the catching-up tendency stabilised around 1992 (the lowest record) and after that the gap in productivity has been rising slowly.

\section{[Insert Figure 5 here]}

The investment-output ratio $(I / O)$ is used in our model as a proxy for physical capital accumulation and its average for the whole period is 30.7\% (see Table 1). Figure 6 shows that the lower records are around 1975 and 1985, respectively, which can be explained by the change of the political regime in the former and by the austerity programs imposed by the IMF in the latter period. A strong increase in investment is observed after Portugal joined the EU and continues up to 1999. After that a downward tendency occurs, which can partly explain the low growth performance of Portugal in the last decade. 


\section{[Insert Figure 6 here]}

The degree of openness (open) is given by the ratio of external trade to GDP and Figure 7 clearly demonstrates that till the beginning of the 1980's the Portuguese economy remained relatively closed, with this indicator fluctuating around $30 \%$. Since 1983 , the economy develops strong trade relations with the rest of the world and especially with the European countries, reaching a degree of openness of nearly $70 \%$ in 2006 . Trade openness and the degree of liberalisation are important factors to explain growth, given the impact they may have on capital accumulation, through the transfer of knowledge and technology. Additionally, trade openness offers new exports' opportunities and the possibility to explore economies of scale due to market size.

\section{[Insert Figure 7 here]}

Soukiazis and Antunes (2012) make a detailed analysis of the Portuguese economy before and after the accession to the EU, in 1986. They conclude that Portugal lost competitiveness in the post-accession period, with exports growing at a slower rate than imports (5.51 and 7.6\%, respectively). Moreover, Portugal grew at a higher rate before joining the EU $(4.39 \%)$ than after $(2.84 \%)$ and the difference to the OECD growth was higher in the former period (0.69 p.p.) than in the latter (0.12 p.p.). The authors argue that the slower growth rate of the Portuguese economy in the post-accession period is not due to the lack of investment but rather to the poorer performance of exports and loss of competitiveness of the economy. On the other hand, the high public deficit and debt ratios Portugal has been accumulating over time (9\% and $93 \%$ in 2010 , respectively), have contributed to the distrust on the country's ability to finance the internal and external imbalances increasing the risk of insolvency. Portuguese 
government issues are no longer default-proof because Portugal relinquished its monetary sovereignty when it joined the euro currency zone. ${ }^{8}$

In the following section we present the structural model to estimate and for that, we take into consideration the variables described above, as well as the interaction between them, to ascertain whether they are able to generate a cumulative causation growth process in the Portuguese economy, in the period from 1965 to 2006.

\section{The structural model}

The model we suggest is derived from the cumulative causation growth theory and the technology gap hypothesis and is formed by the following equations: ${ }^{9}$

$$
y_{t}=a_{1}+a_{2} x_{t}+a_{3} y_{t-1} \quad \text { (export-led growth) }
$$

$$
x_{t}=b_{1}+b_{2} z_{t}+b_{3} p_{t}+b_{4} p m_{t} \quad \text { (growth of exports) }
$$

$$
p_{t}=c_{1}+c_{2} w_{t}+c_{3} \operatorname{prod}_{t} \quad \text { (growth of domestic prices) }
$$

$$
\begin{aligned}
& \operatorname{prod}_{t}=d_{1}+d_{2} y_{t}+d_{3} \operatorname{gap}_{t-1}+d_{4}(I / O)_{t-1} \quad \text { (growth of productivity ) } \\
& (I / O)_{t}=e_{1}+e_{2} y_{t}+e_{3} \text { open }_{t}+e_{4}(I / O)_{t-1} \quad \text { (investment-output ratio) }
\end{aligned}
$$

Equation (1) reflects the idea that export growth $(x)$ is the most potent element of demand inducing faster domestic growth $(y)$, the well known export-led growth hypothesis (Dixon and Thirlwall, 1975). Exports are the autonomous component of demand with the highest multiplier effects on growth (the Hicksian super-multiplier) and enable the growth of induced investment and consumption. Additionally, the lagged 
domestic income growth is introduced, being consistent with the partial adjustment mechanism. All parameters are expected to be positive in this equation.

Equation (2) defines the main determinants of export growth. The explanatory variables are standard: the growth of external demand (z), approximated by the growth of the OECD countries; the growth of domestic prices $(p)$ and that of import prices $(p m)$, capturing the non-price and price competitiveness of exports, respectively. It is expected that the growth of external demand influences the growth of the country's exports positively. The growth of domestic prices is expected to affect export growth negatively, whereas the growth of import prices - reflecting the price competitiveness of foreign competitors - is expected to have a positive impact on the Portuguese export growth.

The formation of domestic prices is explained by equation (3). ${ }^{10}$ The formation of domestic prices is explained by an identity given by 1 plus the mark-up on unit labour costs, and in our model we assume that mark-up is constant. Hence, the growth of domestic prices is explained by the growth of money wages (nominal compensation per employee) and the growth of domestic productivity. Defining in this way the determinants of domestic prices we are consistent with the view that to be competitive in external markets the growth of money wages must not exceed the growth of labour productivity and this is in line with Kaldor's idea of efficiency-wages. Therefore, it is expected that money wages influence positively the growth of domestic prices (wage cost driven inflation) and that gains in productivity contribute to reduce domestic prices.

Equation (4) is an augmented version of "Verdoorn's Law", which relates labour productivity growth (prod) to the domestic output growth (y). The Verdoorn's coefficient is assumed to capture the increasing returns properties associated with 
technical progress, innovation and R\&D activities. ${ }^{11}$ In this equation we add the investment-output ratio (I/O), like Léon-Ledesma (2002), ${ }^{12}$ essentially because growth in productivity also depends on the capacity of the economy to invest in physical capital, like machinery, equipments and infrastructure networks. Depending on the kind of investment, the ratio may reflect the embodied technical progress. The productivity gap variable (gap) aims at capturing any possibility for convergence or catching-up, given that it is an opportunity for the lagging country to adopt better technologies (Amable, 1993). Therefore, productivity in Portugal is expected to grow faster since it is a laggard country relatively to the USA. We intend to verify whether the relative backwardness in terms of technology (captured by labour productivity) ${ }^{13}$ is relevant to explain the productivity growth through the caching-up effect. We expect all coefficients in this equation to be positive.

It was Abramovitz (1986) that first introduced the idea of technological gap ${ }^{14}$ between the more and the less developed economies, which in turn is not per se a sufficient condition for the latter to catch-up with the former in terms of income per head or per worker. For that to be feasible the "social capability" of the economy, related to institutional, educational and social characteristics, has to be taken into account. It is the existence of these two pre-conditions - technological gap and "social capability" - that determines the possibility for an economy to catch-up. The potentiality to catch-up depends on conditions related to the diffusion of knowledge, the rate of structural changes, capital accumulation and the expansion of demand.

The last equation (5) explains the capital accumulation process approximated by the investment-output ratio $(I / O)$ and it is assumed to be endogenous, since it is a byproduct of production and not a cause for it (Kaldor, 1975). The investment-output ratio 
is primarily explained by the growth of output $(y)$, and this is consistent with the accelerator theory. The degree of openness (open) is used as an additional factor to explain physical capital accumulation aiming to capture the technology diffusion mechanism and new investment opportunities through trade. Higher trade is important for the diffusion process facilitating the free movement of knowledge and technology with positive effects on investment. Since investment adjusts partially to its equilibrium level the lagged investment ratio is used to measure the adjustment speed, being consistent with the partial adjustment mechanism. ${ }^{15}$

The basic idea of the model is that exports are the engine of growth inducing a virtuous process of domestic growth with cumulative characteristics. Figure 8 depicts the functioning of the circular and cumulative mechanism and elucidates the causal relationships between the variables.

\section{[Insert Figure 8 here]}

If for any reason the growth of exports $(x)$ increases, it will affect positively the growth of domestic output $(y)$ - through equation (1) - which in turn will increase productivity (prod) - the Verdoorn's effect through equation (4) - turning domestic prices more favourable - through equation (3) - and exports more competitive in international markets - equation (2). Exports will increase further inducing faster growth of domestic output, and the whole process restarts operating in a cumulative way with expanding tendencies. The increase in productivity is responsible for the cumulative tendencies of the process leading to a sustainable expansion of domestic output through higher exports. Productivity growth can also increase by higher accumulation of physical capital $(I / O)$ embodying technical progress - equation (4). Our model allows the accumulation of physical capital to be affected by more intensive trade (open), probably 
through the technology diffusion mechanism - equation (5). The growth of domestic output, exports, domestic prices and productivity, and also capital accumulation are endogenous to the system and they have to be determined simultaneously.

\section{Empirical results}

The method used for estimating the five relations of the system simultaneously is $3 S L S$ (Three-Stage Least Squares) as it is more efficient to capture the interrelation between equations and the causal and feedback effects between the variables. ${ }^{16}$ Table 3 provides the estimation results where simultaneity is controlled by using instrumental variables. Domestic output growth, export growth, domestic prices growth, productivity growth and the investment-output ratio are assumed to be endogenous, and all the other variables of the system are exogenous, serving as instruments.

The obtained results show that this system of structural equations is adequate for explaining the economic performance of Portugal over the period 1965-2006. The goodness of fit is reasonable and the joint significance of all coefficients is highly confirmed, in general terms. Further attempts to improve the results of the export equation (2) by introducing some extra explanatory variables, such as the patents ratio (proxy for innovation), the investment-output ratio (proxy for capital accumulation) whether current or lagged or the enrolment ratio in secondary education (proxy for human capital) were not successful in finding a better fit and statistical significance for these factors. ${ }^{17}$

The first equation of the system expressing the export-led growth hypothesis is robust, showing a strong relation between output growth and export growth. A lagged dependent variable was introduced, to be consistent with the partial adjustment mechanism. The short-run impact with respect to exports is 0.361 and the long-run, 
$0.515,{ }^{18}$ revealing the potentiality of exports as the engine of growth. The speed of adjustment of the actual growth difference towards the desired growth is quite fast, implying that $70 \%$ of this difference is realised within a year.

\section{[Insert Table 3 here]}

The export equation also gives interesting insights. The impact of foreign demand on exports growth is high, showing that a 1 percentage point (p.p.) increase in external demand (approximated by the growth of OECD countries) implies a 3.03 p.p. increase in the Portuguese exports (everything else constant). Portuguese exports are quite elastic with respect to external demand, having the advantage of growing faster in periods of world expansion. That advantage will only become effective if the county is able to increase exports non-price competitiveness, associated with supply characteristics like quality, design, product differentiation, high embodied technology and efficient promotion. However, the high income-elasticity with respect to exports can be a drawback for Portugal when world demand is declining.

In the same equation it is shown that exports are not sensitive with respect to price changes. The impact of domestic prices growth on the demand for exports is positive, an unexpected result, ${ }^{19}$ but it is statistically insignificant. Similarly, the impact of foreign prices (approximated by the growth of import prices) is negative, contrary to what would be expected, but once again, it is not statistically significant. ${ }^{20}$ Moreover, not only the impact of prices on exports is insignificant, but the size of the impact is very small (close to zero) in comparison to that of external demand.

This is important evidence revealing that what matters in international trade is non-price competitiveness captured by the income-elasticity of the demand for exports which in turn is determined by the supply characteristics mentioned earlier. 
The third equation explains the growth of domestic prices mainly by two factors: the growth of money wages (approximated by the growth of nominal compensation per employee) and the growth of labour productivity. In this way we are in line with Kaldor's idea of efficiency-wages as the relevant element for the formation of domestic prices, in order to turn the economy more competitive. Our results reveal some interesting insights with respect to these variables. It is shown that money wages have a positive and statistically significant impact on domestic prices implying that 1 p.p. increase in the former is responsible for a 0.7 p.p. increase in the latter.

This evidence is in accord with the wage-cost push inflation hypothesis. On the other hand, the growth of productivity has its expected negative impact on the growth of domestic prices but it is not statistically significant. This is a disappointing result implying that gains in productivity are not transmitted to prices to turn the economy more competitive. As we have seen in Figure 4, productivity growth is declining towards zero over time and money wages grow faster than productivity. Therefore, efficiency-wages growth is high and this does not help to improve price competitiveness. We detect here a structural problem of the Portuguese economy that can be responsible for the interruption of the cumulative causation process of growth not allowing the economy to grow faster.

The fourth equation of the system explains the growth of domestic productivity based on "Verdoorn's Law". According to this Law, the growth of productivity is explained by the growth of output and this relation captures the static and dynamic increasing returns to scale related to technical progress, innovation and $R \& D$ activities. Our results from Table 3 show that the growth of output is significant for explaining productivity growth implying that every 1 p.p. increase in the former is responsible for a 0.7 p.p. 
increase in the latter. On the other hand, the potentiality for a catching-up effect in productivity levels is confirmed by the positive impact of the productivity gap (lagged one period) on productivity growth. In fact, the distance between the follower (Portugal) and the leader (the USA) in terms of productivity levels is an opportunity for the backward country to imitate and disseminate the advanced foreign technologies. This is in line with Abramovitz's idea of "social capability" in order to catch-up with the leader. The investment-output ratio aiming to capture capital accumulation is also introduced in the productivity equation but its impact is not statistically significant and carries a wrong negative sign. Léon-Ledesma (2002) argues that it is not uncommon to find a negative and/or a statistically insignificant impact of investment-output ratio and that may be explained by the existent colinearity between the domestic output growth and the investment-output ratio.

The last equation explains capital accumulation. Similarly to the output growth regression - equation (1) -, the investment-output ratio follows a partial adjustment process but this time with a relatively slow speed of adjustment. About $31.1 \%$ of the difference between the actual investment ratio and its desired level is realised within the same period. The investment-output ratio is highly explained by internal and external demand conditions given by the growth of domestic output and the degree of openness, respectively. The short-run impact with respect to domestic output growth is 0.49 and in the long-run is even higher - 1.56 - and this is consistent with the accelerator principle. The strength of domestic demand is essential for inducing higher investment. The shortrun effect with respect to the degree of openness is 0.105 and the long-run, 0.34 , revealing that the internationalisation of the economy is responsible for enhancing higher investment accumulation. 
We also regressed each of the equations individually, by $2 S L S$, with all the exogenous variables used as instruments, like previously. The intention was to carry out some diagnostic tests to justify the robustness of our results. The outcomes are reported in Table 4 in the Appendix II.

In general terms, the estimated parameters and their significance do not change when compared to the results from Table 3. However, there are two exceptions: in the export equation the signs of domestic prices $p$ and import prices $p m$ are now correct, although they still remain statistically insignificant; the investment-output ratio $(I / O)$ still has a negative impact on productivity growth but now it is statistically significant at the $5 \%$ level.

We performed four diagnostic tests. The first is the Sargan statistic, a test of overidentifying restrictions to check the validity of the instruments used in the regressions and that hypothesis is confirmed in all cases. The second is the Pagan-Hall heteroscedasticity test, showing that only in the third equation the hypothesis of homoscedasticity is rejected at the $5 \%$ significance level but not at the $1 \%$ level. The third test is the Cumby-Huizinga test for autocorrelation. The null hypothesis is that errors are not first-order autocorrelated and this is confirmed in all cases (in equation (3) at the $1 \%$ significance level but not at the $5 \%$ level). The last one is a normality test, conceptually similar to the Jarque-Bera skewness and kurtosis test. The null hypothesis is that residuals from a given regression are normally distributed, and this hypothesis is not rejected in all equations (at the 5\% significance level for equations (1) and (5) and at the $1 \%$ level for equation (2)).

Given these outcomes and combining the information from Tables $\mathbf{3}$ and $\mathbf{4}$, we can assert that our structural model is robust. However, the cumulative causation growth 
process cannot be confirmed completely since the linkages which turn this process sustainable may be broken in three main points: (i) the investment-output ratio aiming to capture capital accumulation does not significantly affect productivity growth; (ii) the impact of productivity on domestic prices is not relevant, thus preventing the economy from becoming more competitive; (iii) the role of prices on exports is not significant as well, and consequently it does not act as an additional factor for increasing exports competitiveness.

Therefore, we detected some structural setbacks on the Portuguese economy and two of the failing links are related to productivity growth. The lack of a significant impact of (I/O) on productivity growth prevents the country from achieving faster growth rates, enabled by trade openness and technology diffusion that affect capital accumulation. This can also help to explain the declining productivity growth over time observed in Figure 3. Taking into account that money wages grow faster relatively to labour productivity, domestic prices absorb increasing wage costs, preventing the economy from being competitive in terms of prices. The drawback here is explained by the failure in transmitting productivity gains to domestic prices competitiveness.

\section{Conclusion}

This study aims at explaining the growth process of the Portuguese economy since the 1960's by estimating a multi-equation structural model. The basic idea of the model focuses on the cumulative causation principle of the demand-orientated approach, where exports are a crucial element for the growth process.

The structural equations of the model are jointly estimated by $3 S L S$ to capture the causal and feedback effects of the endogenous variables of the system. The results confirm the 
validity of the cumulative causation principle as a useful instrument for describing the Portuguese reality from 1965 to 2006.

Our evidence suggests that the export-led growth equation follows a partial adjustment mechanism with a fast speed of adjustment, with exports having a significant impact on the growth of domestic income, which is consistent with the foreign trade multiplier of the Hicksian type.

The most important determinant of exports is the expansion of external demand. This is a competitive advantage for Portugal implying that exports can grow faster than the growth of external demand and, therefore, attaining faster growth rates of domestic output through the foreign trade multiplier. However, this high dependence on external demand can be harmful to the Portuguese economy in case of an international recession.

The growth of money wages is the major factor contributing to the increase of domestic prices in Portugal and productivity growth gains do not affect domestic prices to turn the economy more competitive. In fact, this evidence has been pointed out as the main structural problem of the Portuguese economy explaining the moderate growth performance especially in the last decade.

Productivity growth is highly explained by the growth of domestic output, and this relation captures substantial returns to scale according to "Verdoorn's Law". The positive effect of the productivity gap on the growth of domestic productivity can be taken as evidence of catching-up or "social capability" implying some kind of knowledge and technology diffusion, as had been stressed by Abramovitz.

The investment-output ratio also follows a partial adjustment process with a slow speed of adjustment. The growth of domestic output has the major impact on capital 
accumulation and this is in line with the accelerator principle. The degree of internationalisation of the economy (through openness) is also important for capital accumulation. Competing in international markets implies higher investment in physical capital, which embodies new technology.

The aim of estimating the model was to show that the relations involved are responsible for generating a cumulative causation growth with self-expanding tendencies. In our study it is shown that the cumulative causation process can be broken in some points that prevent the economy from growing faster. The main failure is found in the productivity equation, explained by the irrelevance of capital accumulation to enhance faster productivity growth. Another concern is about the formation of domestic prices, where productivity is shown to be inappropriate to improve price competitiveness. A third failure is on the export growth, where prices do not matter to improve exports competitiveness. Therefore, there are essential links in the cumulative process that fail to generate higher growth in Portugal. In terms of economic policy, measures are needed to remove these obstacles that prevent the economy from growing faster and most of all policies are required to increase labour productivity. 


\section{Appendix I}

\section{Description of the variables and data sources}

- $y$ - annual growth rate of real GDP - GDP at 1995 (2000) market prices (national currency; annual percentage change).

- $x$ - annual growth rate of real exports - Exports of goods and services at 1995 (2000) prices (national currency; annual percentage change).

- $\quad p m$ - annual growth rate of import prices - Price deflator imports of goods and services (national currency; annual percentage change).

- $\quad p-$ annual growth rate of price deflator GDP at market prices (national currency; annual percentage change).

- prod - annual growth rate of labour productivity - GDP at 1995 (2000) market prices per person employed (annual percentage change).

- $\quad w$ - nominal compensation per employee - total economy (national currency; annual percentage change).

- $w r$ - real compensation per employee; GDP deflator - total economy (national currency; annual percentage change).

Data on $y, x, p m, p$, prod, $w$ and $w r$ were taken from European Commission (2002; 2009). Constant values are at 1995 prices (for 1965-1980) and 2000 prices (for 1981-2006), depending on the Statistical Annex from which they were obtained (2002 and 2009, respectively).

- gap - technological gap, given by one minus the ratio between the level of labour productivity in Portugal over that of the USA. Labour productivity is given by real GDP Laspeyres 2 per worker (2005 constant prices). 
- (I/O) - investment-output ratio, given by the investment share of real GDP (2005 constant prices).

- open - degree of openness, given by the ratio of the real external trade (exports plus imports) over real GDP (2005 constant prices).

Data on labour productivity (to compute gap), (I/O) and open were taken from Heston et al. (2009).

- $z$ - annual growth rate of real foreign income (OECD countries).

1965-1994: GDP at the price levels and exchange rates of 2000 (billions of US dollars) OECD (2006).

1995-2006: Real GDP (\% change from previous year) - OECD (2009). 


\section{Appendix II}

Table 1. Comparative studies of cumulative causation models.

\begin{tabular}{|c|c|c|c|c|c|c|}
\hline Study & $\begin{array}{c}\text { Growth } \\
\text { approach }\end{array}$ & $\begin{array}{c}\text { Exogenous } \\
\text { variables }\end{array}$ & Sample & Period & $\begin{array}{c}\text { Estimation } \\
\text { method }\end{array}$ & $\begin{array}{c}\text { Technology gap } \\
\text { approximated } \\
\text { by }\end{array}$ \\
\hline $\begin{array}{l}\text { Amable } \\
\text { (1993) }\end{array}$ & $\begin{array}{l}\text { Interactions between } \\
\text { equipment investment } \\
\text { share, innovative } \\
\text { activity, education and } \\
\text { productivity growth }\end{array}$ & $\begin{array}{l}\text {-technology gap (follower) } \\
-\% \text { of concerned age group } \\
\text { engaging in primary education } \\
-\% \text { of real government } \\
\text { expenditure }\end{array}$ & $\begin{array}{l}59 \\
\text { countries }\end{array}$ & $1960-85$ & FIML & $\begin{array}{l}\text { (real GDP per } \\
\text { worker level in } \\
\text { country } i \\
\text { relatively to the } \\
\text { USA's) }\end{array}$ \\
\hline $\begin{array}{l}\text { Targetti } \\
\text { and Foti } \\
(1997)\end{array}$ & $\begin{array}{l}\text { Interactions between } \\
\text { output growth, } \\
\text { productivity and } \\
\text { exports }\end{array}$ & $\begin{array}{l}\text {-world productivity } \\
\text {-world demand } \\
\text {-technology gap } \\
\text {-investment-output ratio }\end{array}$ & $\begin{array}{l}25 \\
\text { countries }\end{array}$ & $1950-88$ & $\begin{array}{l}\text { iterative } \\
3 S L S\end{array}$ & $\begin{array}{l}\text { ln (GDP per } \\
\text { worker level in } \\
\text { USA relatively to } \\
\text { the country } i \text { 's) }\end{array}$ \\
\hline $\begin{array}{l}\text { Fingleton } \\
(2000)\end{array}$ & $\begin{array}{l}\text { Interactions between } \\
\text { productivity, } \\
\text { investment share, } \\
\text { R\&D activity, } \\
\text { education and } \\
\text { aggregate output } \\
\text { growth }\end{array}$ & $\begin{array}{l}\text {-technology gap } \\
\text {-weighted average of the level } \\
\text { of technology in neighbouring } \\
\text { countries } \\
\text {-primary education }\end{array}$ & $\begin{array}{l}60 \\
\text { countries }\end{array}$ & $1960-85$ & FIML & $\begin{array}{l}\text { 1-( productivity } \\
\text { level in country } i \\
\text { relatively to the } \\
\text { USA's) }\end{array}$ \\
\hline $\begin{array}{l}\text { Greunz } \\
(2001)\end{array}$ & $\begin{array}{l}\text { Interactions between } \\
\text { output growth, the } \\
\text { proportion of industrial } \\
\text { and service } \\
\text { employment, and the } \\
\text { innovative activity }\end{array}$ & $\begin{array}{l}\text {-technology gap (follower) } \\
\text {-physical infrastructures } \\
\text {-level of qualification of the } \\
\text { working-age population } \\
\text {-real R\&D expenditures }\end{array}$ & $\begin{array}{l}153 \\
\text { European } \\
\text { regions }\end{array}$ & $1989-96$ & $\overline{F I M L}$ & $\begin{array}{l}\text { (real GDPpc } \\
\text { level in region } i \\
\text { relatively to the } 3 \\
\text { best performing } \\
\text { regions) }\end{array}$ \\
\hline $\begin{array}{l}\text { Castellacci } \\
(2002)\end{array}$ & $\begin{array}{l}\text { Interactions between } \\
\text { output growth, exports } \\
\text { growth, domestic } \\
\text { prices, average } \\
\text { productivity, } \\
\text { knowledge stock } \\
\text { (leader and follower), } \\
\text { technology gap and } \\
\text { innovative activity }\end{array}$ & $\begin{array}{l}\text {-technology gap } \\
\text {-world demand } \\
\text {-money wages } \\
\text {-level of education of the } \\
\text { working population } \\
\text {-investment-output ratio }\end{array}$ & $\begin{array}{l}26 \text { OECD } \\
\text { countries }\end{array}$ & 1991-99 & $\begin{array}{l}\mathrm{k} \text {-means } \\
\text { clustering } \\
\text { algorithm }\end{array}$ & $\begin{array}{l}\text { ln (ratio of R\&D } \\
\text { on GDP in the } \\
\text { leader relatively } \\
\text { to the follower's) }\end{array}$ \\
\hline $\begin{array}{l}\text { Léon- } \\
\text { Ledesma } \\
(2002)\end{array}$ & $\begin{array}{l}\text { Interactions between } \\
\text { output growth, exports, } \\
\text { domestic prices, } \\
\text { productivity and } \\
\text { innovation }\end{array}$ & $\begin{array}{l}\text {-technology gap } \\
\text {-growth of foreign prices } \\
\text {-world income growth } \\
\text {-investment-output ratio } \\
\text {-growth of money wages } \\
\text {-rate of growth of the } \\
\text { cumulative sum of real output } \\
\text {-level of education of the } \\
\text { working population }\end{array}$ & $\begin{array}{l}17 \text { OECD } \\
\text { countries }\end{array}$ & $1965-94$ & $\begin{array}{l}\text { iterative } \\
3 S L S\end{array}$ & $\begin{array}{l}\text { 1-( productivity } \\
\text { level in country } i \\
\text { relatively to the } \\
\text { USA's) }\end{array}$ \\
\hline
\end{tabular}

Data source: Authors' elaboration, using the cited references. 
Table 2. Descriptive statistics of variables, 1965-2006 (42 observations).

\begin{tabular}{c|cccc}
\hline Variable & Mean & Std. Deviation & Min & Max \\
\hline $\begin{array}{c}\text { (1) } y \% \\
\text { Domestic income }\end{array}$ & 3.70 & 3.26 & -4.3 & 11.2 \\
\hline $\begin{array}{c}(2) z \% \\
\text { Foreign income }\end{array}$ & 3.26 & 1.51 & 0.1 & 6.3 \\
\hline $\begin{array}{c}\text { (3) } x \% \\
\text { Exports }\end{array}$ & 6.18 & 7.94 & -16.4 & 33 \\
\hline $\begin{array}{c}\text { (4) } \mathrm{p} \% \\
\text { Domestic prices }\end{array}$ & 10.37 & 7.78 & 1.4 & 26.5 \\
\hline $\begin{array}{c}\text { (5) } \text { pm } \% \\
\text { Import prices }\end{array}$ & 9.13 & 12.11 & -6.8 & 43.8 \\
\hline $\begin{array}{c}\text { (6) } \mathrm{w} \% \\
\text { Nominal compensation per employee }\end{array}$ & 14.13 & 8.72 & 2.1 & 35.1 \\
\hline $\begin{array}{c}\text { (7) wr } \% \\
\text { Real compensation per employee }\end{array}$ & 3.46 & 4.71 & -2.9 & 18.6 \\
\hline $\begin{array}{c}\text { (8) prod } \% \\
\text { Productivity }\end{array}$ & 3.39 & 3.02 & -3.2 & 11.7 \\
\hline $\begin{array}{c}\text { (9) gap } \\
\text { Productivity gap }\end{array}$ & 56.31 & 5.99 & 49.1 & 71.3 \\
\hline $\begin{array}{c}\text { (10) (I/O) } \\
\text { Investment-output ratio }\end{array}$ & 30.70 & 4.40 & 19.1 & 38.7 \\
\hline $\begin{array}{c}\text { (11) open } \\
\text { Degree of openness }\end{array}$ & 42.12 & 13.12 & 25.7 & 69.1 \\
\hline
\end{tabular}

Data sources: European Commission (2002; 2009); Heston et al. (2009) and OECD (2006; 2009). Notes: Variables (1) to (8) are annual growth rates. Variables (9) to (11) are ratios.

Figure 1. Annual growth rate of domestic (y) and foreign income (z), 1965-2006.

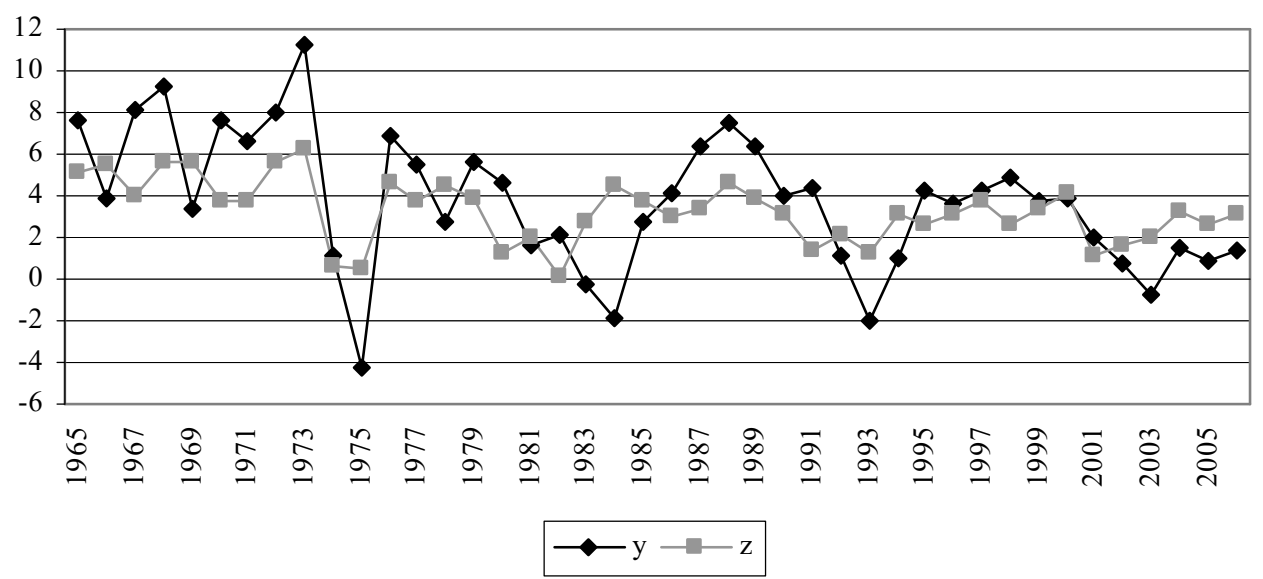

Data source: European Commission (2002; 2009) and OECD (2006; 2009). 
Figure 2. Annual growth rate of exports $(x)$, 1965-2006.

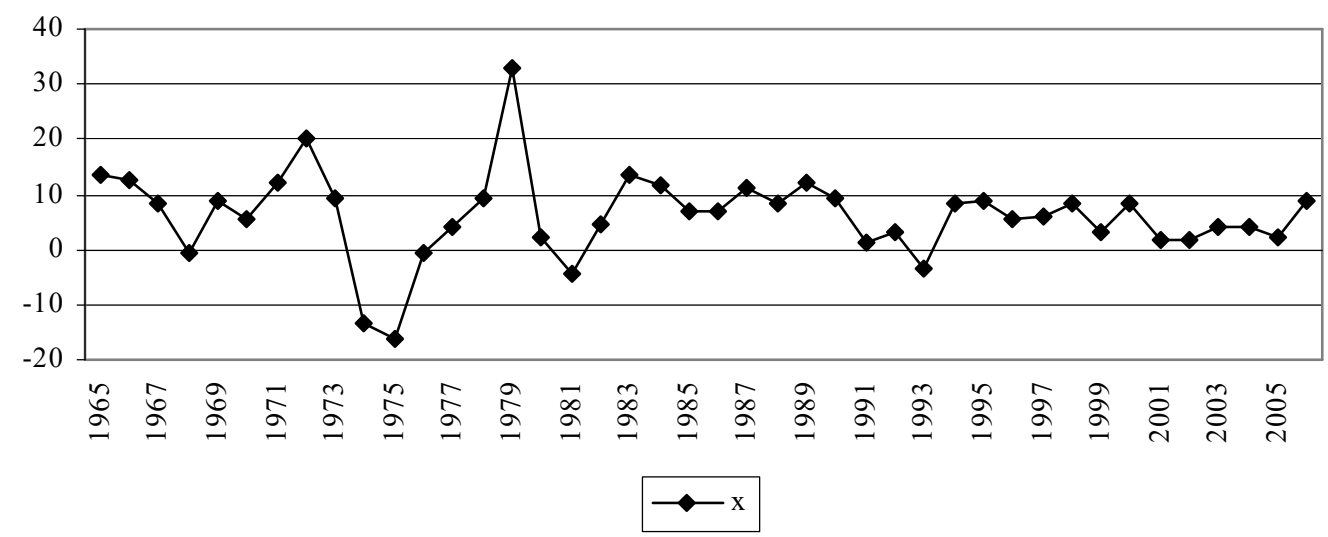

Data source: European Commission (2002; 2009).

Figure 3. Annual growth rate of domestic (p) and import prices $(p m), 1965-2006$.

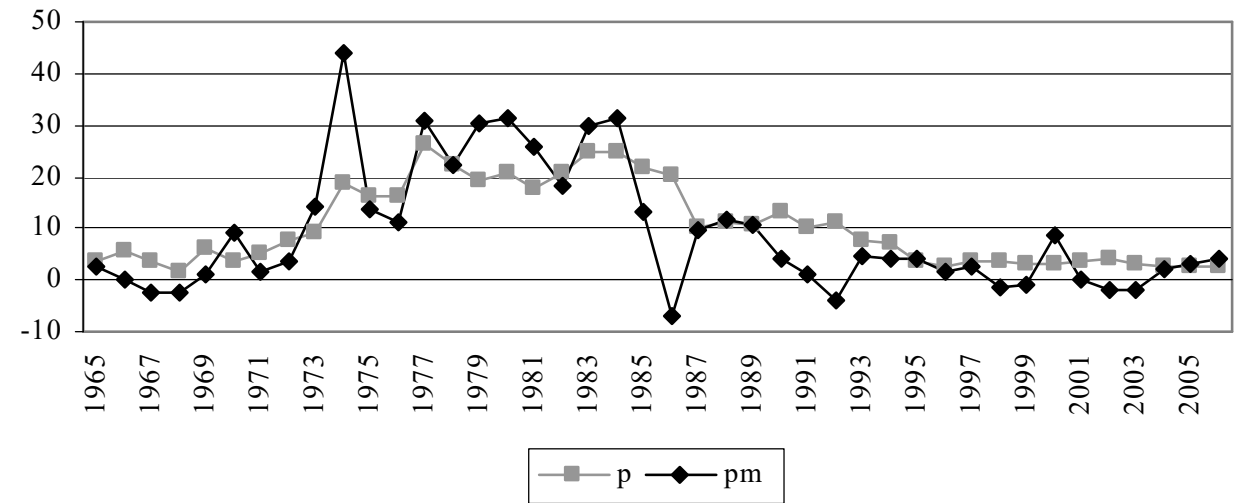

Data source: European Commission (2002; 2009). 
Figure 4. Annual growth rate of nominal $(w)$ and real compensation per employee (wr) and of productivity (prod), 1965-2006.

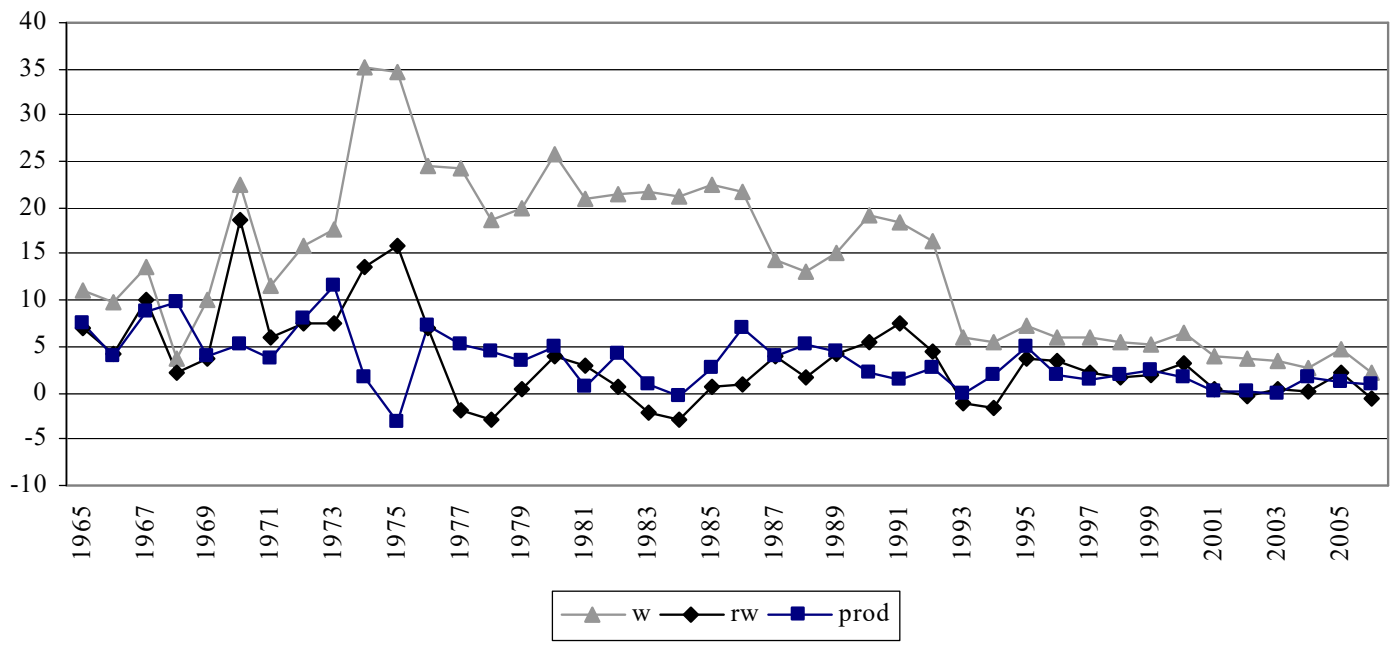

Data source: European Commission (2002; 2009).

Figure 5. Productivity gap relative to the USA (gap), 1965-2006.

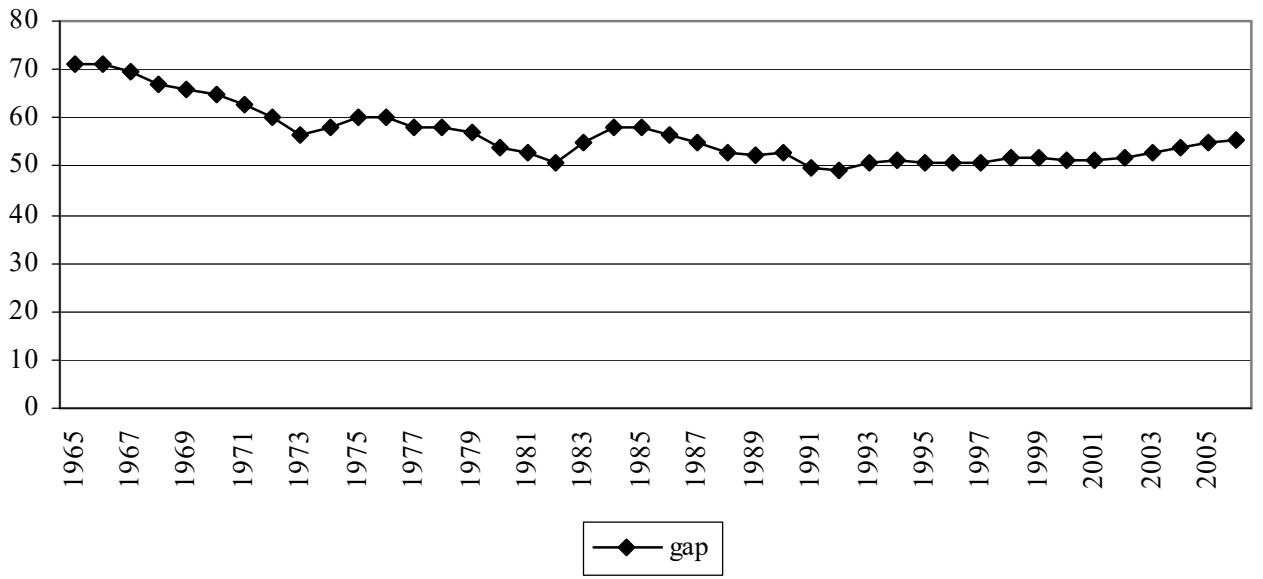

Data source: Authors' computation using data from Heston et al. (2009). 
Figure 6. Investment-output ratio (I/O), 1965-2006.

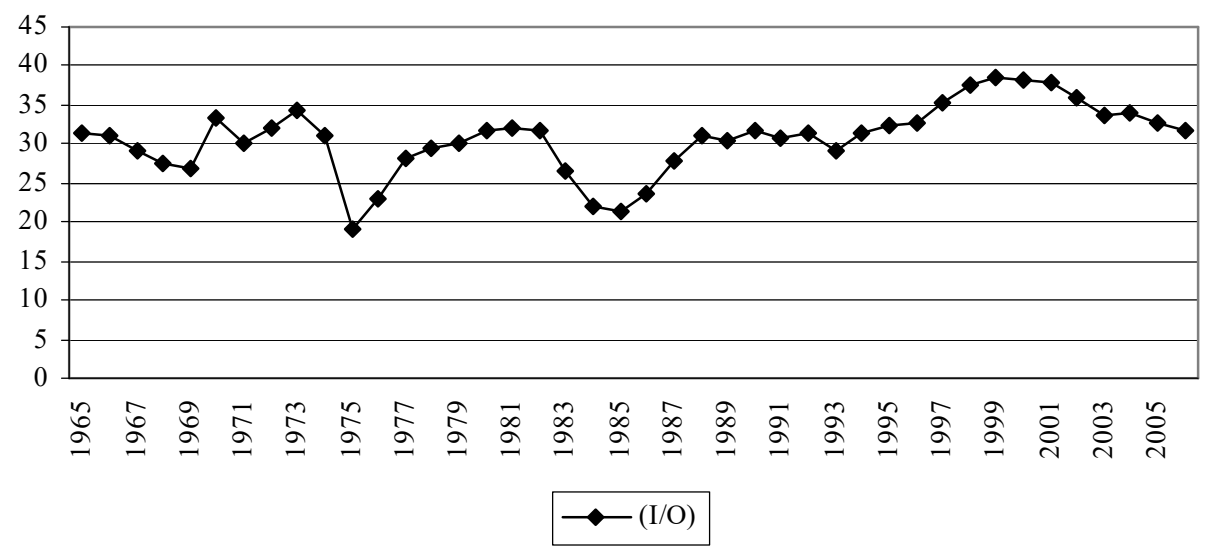

Data source: Heston et al. (2009).

Figure 7. Degree of openness (open), 1965-2006.

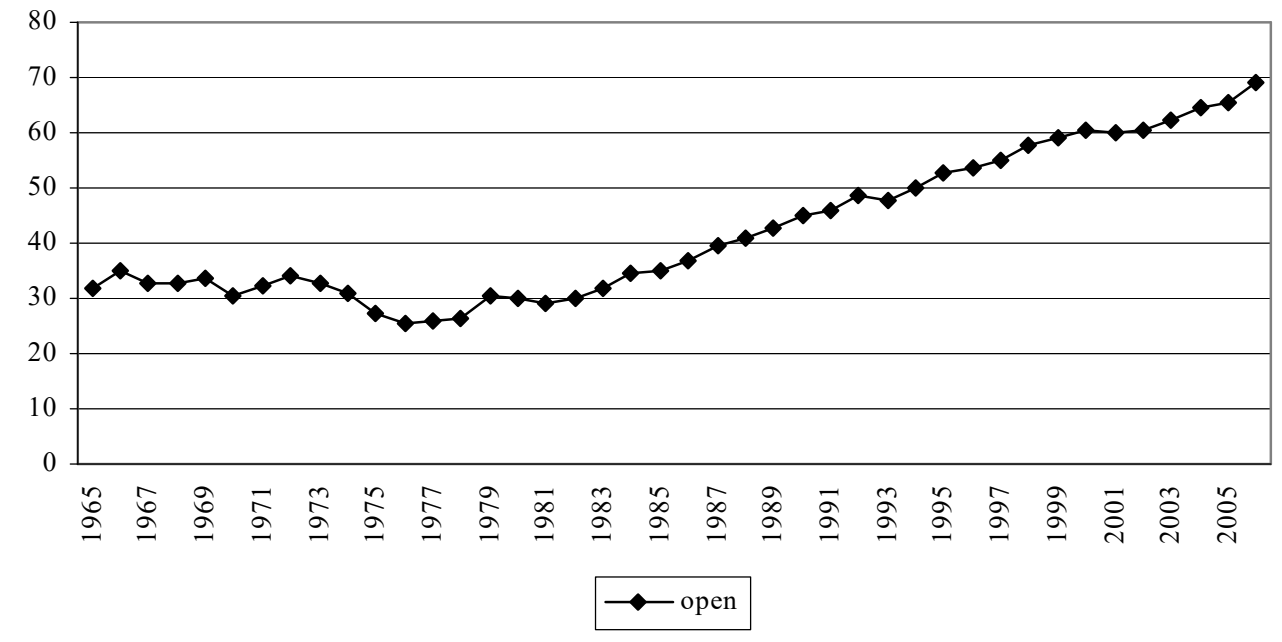

Data source: Heston et al. (2009).

Figure 8. The circular and cumulative mechanism

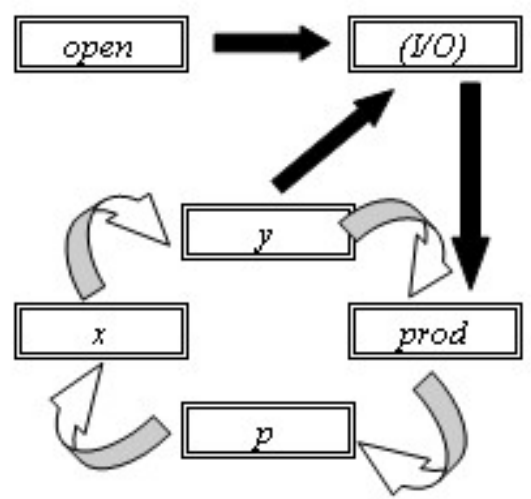

Data source: Authors' elaboration. 
Table 3. The 3SLS estimation of the cumulative growth model, 1965-2006.

\begin{tabular}{|c|c|c|c|c|c|c|c|}
\hline & Coefficient & Std Error & t-stat & p-value & $\mathbf{R}^{2}$ & F-stat & p-value \\
\hline Export-led growth & \multicolumn{7}{|c|}{ (Dependent variable: $y_{t}$ ) } \\
\hline $\mathrm{x}_{\mathrm{t}}$ & 0.361 & 0.083 & 4.35 & $0.000 * * *$ & \multirow{3}{*}{0.119} & \multirow{3}{*}{13.30} & \multirow{3}{*}{0.000} \\
\hline $\mathrm{y}_{\mathrm{t}-1}$ & 0.299 & 0.110 & 2.71 & $0.007 * * *$ & & & \\
\hline constant & 0.325 & 0.788 & 0.41 & 0.681 & & & \\
\hline Growth of exports & \multicolumn{7}{|c|}{ (Dependent variable: $x_{t}$ ) } \\
\hline $\mathrm{Z}_{\mathrm{t}}$ & 3.034 & 0.650 & 4.67 & $0.000 * * *$ & \multirow{4}{*}{0.2953} & \multirow{4}{*}{8.14} & \multirow{4}{*}{0.000} \\
\hline $\mathrm{p}_{\mathrm{t}}$ & 0.035 & 0.211 & 0.17 & 0.869 & & & \\
\hline $\mathrm{pm}_{\mathrm{t}}$ & -0.087 & 0.122 & -0.71 & 0.476 & & & \\
\hline Constant & -3.268 & 2.854 & -1.14 & 0.254 & & & \\
\hline Growth of domestic prices & \multicolumn{7}{|c|}{ (Dependent variable: $p_{t}$ ) } \\
\hline $\mathrm{w}_{\mathrm{t}}$ & 0.735 & 0.073 & 10.11 & $0.000 * * *$ & \multirow{3}{*}{0.6543} & \multirow{3}{*}{51.52} & \multirow{3}{*}{0.000} \\
\hline $\operatorname{prod}_{\mathrm{t}}$ & -0.128 & 0.294 & -0.44 & 0.664 & & & \\
\hline Constant & 0.427 & 1.501 & 0.28 & 0.776 & & & \\
\hline Growth of productivity & \multicolumn{7}{|c|}{ (Dependent variable: $\operatorname{prod}_{t}$ ) } \\
\hline $\mathrm{y}_{\mathrm{t}}$ & 0.695 & 0.119 & 5.85 & $0.000 * * *$ & \multirow{4}{*}{0.8164} & \multirow{4}{*}{44.99} & \multirow{4}{*}{0.000} \\
\hline $\operatorname{gap}_{\mathrm{t}-1}$ & 0.098 & 0.043 & 2.26 & $0.025 * *$ & & & \\
\hline$(\mathrm{I} / \mathrm{O})_{\mathrm{t}-1}$ & -0.058 & 0.046 & -1.26 & 0.210 & & & \\
\hline Constant & -2.955 & 2.827 & -1.05 & 0.297 & & & \\
\hline Investment-output ratio & \multicolumn{7}{|c|}{ (Dependent variable: $\left.(I / O)_{t}\right)$} \\
\hline $\mathrm{y}_{\mathrm{t}}$ & 0.490 & 0.146 & 3.35 & $0.001 * * *$ & \multirow{4}{*}{0.7814} & \multirow{4}{*}{46.44} & \multirow{4}{*}{0.000} \\
\hline open $_{t}$ & 0.105 & 0.031 & 3.37 & $0.001 * * *$ & & & \\
\hline$(\mathrm{I} / \mathrm{O})_{\mathrm{t}-1}$ & 0.689 & 0.090 & 7.63 & $0.000 * * *$ & & & \\
\hline Constant & 3.354 & 2.579 & 1.30 & 0.195 & & & \\
\hline
\end{tabular}

Notes:

Endogenous variables: $y_{t}, x_{t}, p_{t}, \operatorname{prod}_{t},(I / O)_{t}$. Exogenous variables: $y_{t-1}, z_{t}$, pm $_{t}, w_{t}, \operatorname{gap}_{t-1},(I / O)_{t-1}$, open $_{t}$.

* Coefficient significant at the $10 \%$ level;** Coefficient significant at the $5 \%$ level; *** Coefficient significant at the $1 \%$ level. 
Table 4. The 2SLS estimation of each equation of the cumulative growth model,

1965-2006.

\begin{tabular}{|c|c|c|c|c|c|c|c|c|}
\hline & Coefficient & $\begin{array}{l}\text { Std. } \\
\text { Error }\end{array}$ & t-stat & p-value & $\begin{array}{l}\text { Sargan } \\
\text { statistic }\end{array}$ & $\begin{array}{c}\text { Heteroscedasticity } \\
\text { test }\end{array}$ & $\begin{array}{c}\mathrm{AR}(1) \\
\text { test }\end{array}$ & $\begin{array}{c}\text { Normality } \\
\text { test }\end{array}$ \\
\hline \multicolumn{9}{|l|}{$\begin{array}{l}\text { Export-led } \\
\text { growth }\end{array}$} \\
\hline $\mathrm{X}_{\mathrm{t}}$ & 0.298 & 0.093 & 3.22 & $0.003 * * *$ & $X^{2}=7.832$ & $X^{2}{ }^{2}=9.492$ & $X^{2}{ }_{1}=0.0716$ & $X^{2}{ }_{2}=5.30$ \\
\hline $\mathrm{y}_{\mathrm{t}-1}$ & 0.400 & 0.138 & 2.89 & $0.006^{* * *}$ & $\mathrm{p}$-value $=0.1657$ & $\mathrm{p}$-value $=0.2193$ & $\mathrm{p}$-value $=0.7890$ & p-value $=0.0707$ \\
\hline Constant & 0.326 & 0.863 & 0.38 & 0.708 & & & & \\
\hline \multicolumn{9}{|l|}{$\begin{array}{c}\text { Growth of } \\
\text { exports }\end{array}$} \\
\hline $\mathrm{Zt}$ & 2.947 & 0.817 & 3.61 & $0.001 * * *$ & $X^{2}{ }^{2}=3.118$ & $X^{2} 7=9.175$ & $X^{2}{ }_{1}=1.8090$ & $X^{2}{ }^{2}=9.20$ \\
\hline $\mathrm{p}_{\mathrm{t}}$ & -0.132 & 0.310 & -0.42 & 0.674 & $\mathrm{p}$-value $=0.5382$ & $\mathrm{p}$-value $=0.2403$ & $\mathrm{p}$-value $=0.1786$ & $\mathrm{p}$-value $=0.0101$ \\
\hline $\mathrm{pm}_{\mathrm{t}}$ & 0.090 & 0.175 & 0.52 & 0.609 & & & & \\
\hline Constant & -2.880 & 3.794 & -0.76 & 0.452 & & & & \\
\hline \multicolumn{9}{|c|}{$\begin{array}{c}\text { Growth of } \\
\text { domestic prices }\end{array}$} \\
\hline $\mathrm{W}_{\mathrm{t}}$ & 0.726 & 0.111 & 6.55 & $0.000 * * *$ & $X^{2}=2.364$ & $X^{2}{ }^{2}=15.850$ & $X^{2}{ }_{1}=4.4853$ & $X^{2}{ }_{2}=3.16$ \\
\hline $\operatorname{prod}_{t}$ & -0.295 & 0.229 & -1.29 & 0.204 & $\mathrm{p}$-value $=0.7969$ & $\mathrm{p}$-value $=0.0265$ & $\mathrm{p}$-value $=0.0342$ & p-value $=0.2064$ \\
\hline Constant & 1.110 & 1.051 & 1.06 & 0.297 & & & & \\
\hline \multicolumn{9}{|l|}{$\begin{array}{c}\text { Growth of } \\
\text { productivity }\end{array}$} \\
\hline $\mathrm{yt}_{\mathrm{t}}$ & 0.716 & 0.130 & 5.48 & $0.000 * * *$ & $X^{2}{ }^{2}=2.431$ & $X^{2} 7=8.860$ & $X^{2}{ }_{1}=0.1697$ & $X^{2}{ }_{2}=1.96$ \\
\hline $\operatorname{gap}_{\mathrm{t}-1}$ & 0.070 & 0.049 & 1.43 & 0.160 & $\mathrm{p}$-value $=0.6571$ & p-value $=0.2629$ & $\mathrm{p}$-value $=0.6804$ & $\mathrm{p}$-value $=0.3753$ \\
\hline$(\mathrm{I} / \mathrm{O})_{\mathrm{t}-1}$ & -0.108 & 0.051 & -2.12 & $0.041 * *$ & & & & \\
\hline Constant & 0.091 & 3.179 & 0.03 & 0.977 & & & & \\
\hline \multicolumn{9}{|l|}{$\begin{array}{l}\text { Investment- } \\
\text { output ratio } \\
\end{array}$} \\
\hline $\mathrm{yt}_{\mathrm{t}}$ & 0.463 & 0.166 & 2.79 & $0.008 * * *$ & $X^{2}{ }^{2}=6.858$ & $X^{2} 7=10.304$ & $X^{2}{ }_{1}=1.4897$ & $X^{2}{ }_{2}=5.92$ \\
\hline open $_{t}$ & 0.106 & 0.033 & 3.18 & $0.003 * * *$ & $\mathrm{p}$-value $=0.1436$ & $\mathrm{p}$-value $=0.1720$ & $\mathrm{p}$-value $=0.2223$ & p-value $=0.0517$ \\
\hline$(\mathrm{I} / \mathrm{O})_{\mathrm{t}-1}$ & 0.649 & 0.112 & 5.78 & $0.000 * * *$ & & & & \\
\hline Constant & 4.651 & 2.871 & 1.62 & 0.113 & & & & \\
\hline
\end{tabular}

Notes:

Equations (2) and (5) were estimated with the bw(auto) option. Therefore, the automatic bandwith selection procedure of Newey and West is chosen, with the default Bartlett kernel. The estimates are efficient for homoscedasticity and the statistics are robust to autocorrelation.

Equation (3) was estimated with the bw(auto) and robust options, thus requesting HAC standard errors that are robust to both arbitrary heteroscedasticity and arbitrary autocorrelation. In this case, we have robust standard errors and the Hansen-J statistic instead of the Sargan statistic.

* Coefficient significant at the $10 \%$ level; $* *$ Coefficient significant at the $5 \%$ level; *** Coefficient significant at the $1 \%$ level. 


\section{References}

Abramovitz, M. (1986) Catching-up, forging ahead and falling behind, Journal of Economic History, 46, 2, pp.385-406.

AlDakhil, K. (1998) A method for estimating simultaneous equations models with timeseries and cross-section data, Journal of King Saud University - Administrative Sciences, 10, 1, pp.13-28.

Amable, B. (1993) Catch-up and convergence: a model of cumulative growth, International Review of Applied Economies, 7, 1, pp.1-25.

Atesoglu, H. (1994) An application of a Kaldorian export-led model of growth to the United States, Applied Economics, 26, pp.479-83.

Bairam, E. (1988) Balance-of-payments, the Harrod foreign trade multiplier and economic growth: the European and North American experience, 1970-1985, Applied Economics, 20, pp.1635-42.

Blecker, R. (2009) Long-run growth in open economies: export-led cumulative causation or a balance-of-payments constraint?, Paper presented at the $2^{\text {nd }}$ Summer School on Keynesian Macroeconomics and European Economic Policies, $2^{\text {nd }} 9^{\text {th }}$ August, Berlin, Germany.

Castellacci, F. (2002) Technology-gap and cumulative growth: models, results and performances, Centre for Technology, Innovation and Culture, pp. 1-35.

Caixa Geral de Depósitos (2012) Exportação, valor e crescimento, Relatórios CGD Desenvolvimento da economia portuguesa, Lisboa, Setembro. 
De Benedictis, L. (1998) Cumulative causation, Harrod's trade multiplier and Kaldor's paradox: foundations of post-Keynesian theory and growth differentials, in Rampa, G., Stella, L. and Thirlwall, A. (eds), Economic Dynamics, Trade and Growth: Essays on Harrodian Themes, Basingstoke, Macmillan.

Dixon, R.; Thirlwall, A. (1975) A model of regional growth-rate differences on Kaldorian lines, Oxford Economic Papers, 27, pp.201-214.

European Commission (2002) Statistical Annex of European Economy, Directorate General Economic and Financial Affairs, Spring.

European Commission (2009) Statistical Annex of European Economy, Directorate General Economic and Financial Affairs, Spring.

Fingleton, B. (2000) Convergence: international comparisons based on a simultaneous equation model with regional effects, International Review of Applied Economics, 14, 3, pp.285-305.

Greunz, L. (2001) European regional growth, technology gap and R\&D efforts, Paper presented at the $41^{\text {st }}$ Annual ERSA Congress, $29^{\text {th }}$ August- $1^{\text {st }}$ September, Zagreb, Croatia.

Kaldor, N. (1957) A model of economic growth, The Economic Journal, 67, pp.591624.

Kaldor, N. (1966) Causes of the slow rate of economic growth in the United Kingdom, in Targetti, F. and Thirlwall, A. (eds) The Essential Kaldor, London, Duckworth.

Kaldor, N. (1970) The case for regional growth policies, in Targetti, F. and Thirlwall, A. (eds) The Essential Kaldor, London, Duckworth. 
Kaldor, N. (1975) What is wrong with economic theory, The Quarterly Journal of Economics, 89, 3, August, pp.347-357.

Kaldor, N. (1978) The effect of devaluations on trade in manufactures. in Kaldor, N. Further Essays on Applied Economics, London, Duckworth.

Kaldor, N. (1981) The role of increasing returns, technical progress and cumulative causation in the theory of international trade and economic growth, in Targetti, F. and Thirlwall, A. (eds) The Essential Kaldor, London, Duckworth.

Kelton, S.; Wray, R. (2009) Can Euroland survive?, Public Policy Brief no.106, The Levy Economics Institute of Bard College, pp.1-20.

Léon-Ledesma, M. (2002) Accumulation, innovation and catching-up: an extended cumulative growth model, Cambridge Journal of Economics, 26, pp.201-216.

Myrdal, G. (1957) Economic theory and under-developed regions, London, Duckworth.

Organization for Economic Co-operation and Development - OECD (2006) Statistical Compendium: National Accounts and Historical Statistics 1962-2004, Paris.

Organization for Economic Co-operation and Development - OECD (2009) Economic Outlook no. 85 Annex Tables, Paris, June.

Pini, P. (1996) An integrated model of cumulative growth: empirical evidence for nine OECD countries, 1960-1999, Labour, 10, 1, pp.93-150.

Soukiazis, E.; Antunes, M. (2012) Application of the balance-of-payments-constrained growth model to Portugal, 1965-2008, Journal of Post Keynesian Economics, 34, 2, pp. 353-379. 
Targetti, F.; Foti, A. (1997) Growth and productivity: a model of cumulative growth and catching-up, Cambridge Journal of Economics, 21, pp.27-43.

Wooldridge, J. (2002) Econometric analysis of cross-section and panel data, Cambridge, Massachusetts, MIT Press. 


\section{Endnotes}

1 The non-tradable sector has gained relevance in the Portuguese economy, going from $74 \%$ of the value added in 1995 to $82 \%$ in 2008 , when evaluated in terms of sectors of production. Moreover, considering the export orientated industry, in 2008 the low-technology sector employed 54\% of the labour force, the medium-low technology was responsible for $25 \%$ and the high-technology 21\%, respectively (source: Caixa Geral de Depósitos, 2012).

2 The Kaldorian view is part of the Keynesian approach to growth and it emphasises the role of prices on growth, in short- to medium-run contexts (Blecker, 2009).

3 For a comparative survey on the Post-Keynesian perspectives of the export-led cumulative causation growth and the balance-of-payments constraint approach, see Blecker (2009).

4 The circular and cumulative growth models mentioned in Table 1 are cross-section studies to explain short to medium-run growth. We use a time-series analysis of 42 annual observations to explain a relatively long-run growth performance of the Portuguese economy.

5 For the description of the variables, see the Appendix.

6 Although the OECD sample includes Portugal, the rate of OECD income growth with Portugal is not substantially different from the one excluding it. Therefore, foreign income is approximated by the growth rate of the OECD countries. This is a reasonable proxy, since more than $80 \%$ of Portuguese imports and exports are associated with these countries. For details on the computation of $z$, see the Appendix.

7 Nominal compensation per employee will be referred to as nominal wages in the text, for simplicity.

8 A country enjoys monetary sovereignty if its debt obligations are denominated in a currency of which it is the monopoly issuer. See Kelton and Wray (2009).

9 All variables in the system are expressed in growth rates, except gap, $(I / O)$ and open, which are ratios. 
10 Export prices are a proxy for domestic prices. We alternatively used the growth rate of the GDP price deflator as a proxy for domestic prices, but no reasonable results were obtained.

11 For more details see Kaldor (1975).

12 But contrary to Léon-Ledesma (2002), we consider the investment-output ratio as endogenous.

13 Castellacci (2002) used the relative ratio of R\&D expenditures on GDP as a proxy for technological gap (see

Table 1).

14 For a broader discussion about the technology gap literature, see for instance, Castellacci (2002).

15 In a preliminary work we included the patents ratio (proxy for innovation) as an explanatory factor of the investment-output ratio, but no satisfactory results were accomplished.

16 For more details on the $3 S L S$ method, see for instance, AlDakhil (1998) and Wooldridge (2002).

17 Additionally, estimations of the system were run with modified variables, smoothed by the Hodrick-Prescott filter, and alternatively by the moving-average. Also, estimations with stationary variables were carried out. The idea was to avoid short-run cyclical influences and biases of the estimates. However, no reasonable outcomes were obtained and the idea of working with modified data was abandoned.

18 The long-run impact is given by: $0.361 /(1-0.299)=0.515$.

19 The (unexpected) positive impact of relative prices on exports was also found by Bairam (1988) for Portugal, during 1970-1985. Antunes and Soukiazis (2009) also found a positive impact of relative prices on exports, for Portugal during 1965-2008. However, the magnitude of the impact is very low when compared to that of income.

20 We opted to separate the impacts of domestic and import prices growth in equation (2) instead of using relative prices growth (the difference between the two variables). The reason is that we assume domestic price growth as endogenous and import prices growth as exogenous. Thus, the consideration of relative prices would make this distinction difficult. 